PETER BEILHARZ

I N I M A C Y

I N

$P \bigcirc S T$

M
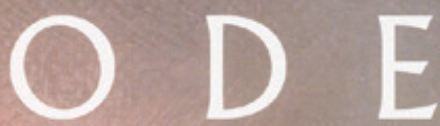

R

$\mathrm{N}$

T

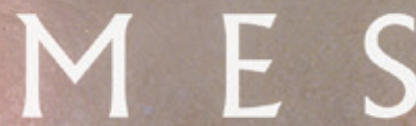

A FRIEN D S H I P

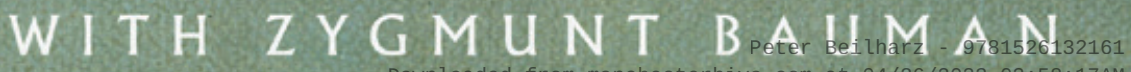
Downloaded from manchesterhive.com at 04/26/2023 03:58:17 AM 


\section{Intimacy in postmodern times}

\section{MANCHESTER 1824}

Manchester University Press 
Peter Beilharz - 9781526132161

Downloaded from manchesterhive.com at $04 / 26 / 2023$ 03:58:17AM 
Intimacy in

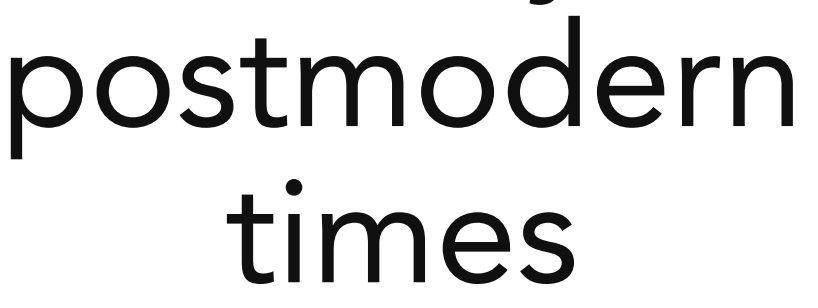

A friendship with Zygmunt Bauman

\author{
Peter Beilharz
}

Manchester University Press 


\section{Copyright (C) Peter Beilharz 2020}

The right of Peter Beilharz to be identified as the author of this work has been asserted by him in accordance with the Copyright, Designs and Patents Act 1988.

Published by Manchester University Press

Altrincham Street, Manchester M1 7JA

www.manchesteruniversitypress.co.uk

British Library Cataloguing-in-Publication Data

A catalogue record for this book is available from the British Library

ISBN 9781526132154 hardback

First published 2020

The publisher has no responsibility for the persistence or accuracy of URLs for any external or third-party internet websites referred to in this book, and does not guarantee that any content on such websites is, or will remain, accurate or appropriate.

Cover design: Daniel Benneworth-Gray

Typeset by Newgen Publishing UK 